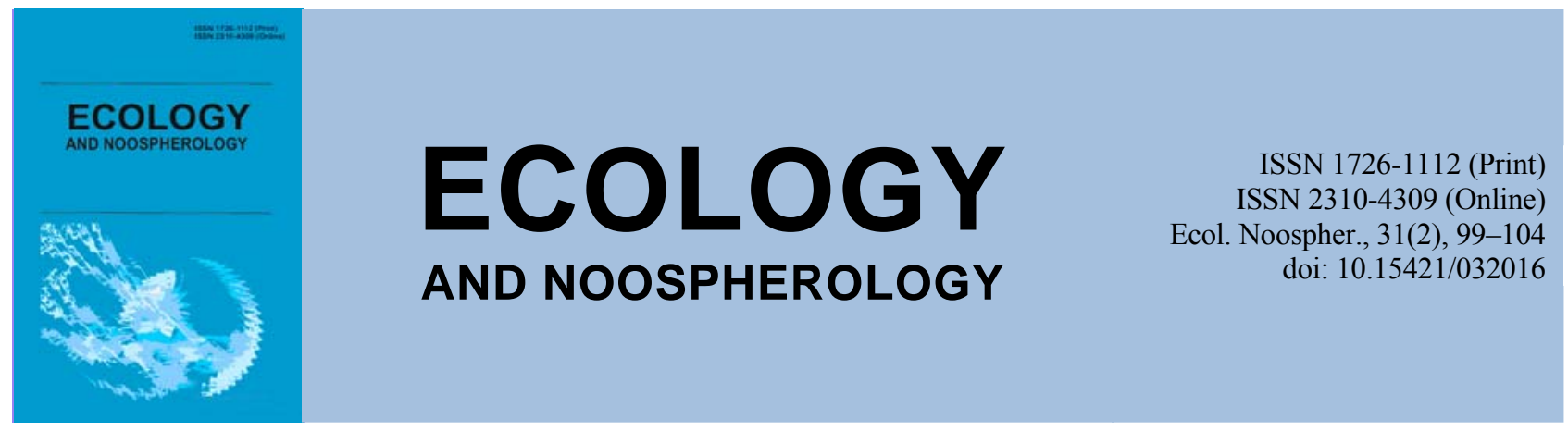

\title{
Road network forms specific stations for living organisms in the conditions of the steppe zone
}

\author{
S. V. Yermolenko, A. O. Huslystyi, A. M. Hahut, V. Ya. Gasso, I. A. Ivanko \\ Oles Honchar Dnipro National University, Dnipro, Ukraine
}

Article info

Received 08.10.2020

Received in revised form

17.10.2020

Accepted 25.10.2020

Oles Honchar Dnipro

National University,

Gagarin Ave., 72, Dnipro,

49010, Ukraine.

Tel.: +38-095-173-62-18

E-mail: Yermolenko_sv@i.ua
Yermolenko, S. V., Huslystyi, A. O., Hahut, A. M., Gasso, V. Ya., Ivanko, I. A. (2020). Road network forms specific stations for living organisms in the conditions of the steppe zone. Ecology and Noospherology, 31(2), 99-104. doi:10.15421/032016

The state of art analysis of available published data allowed to determine the features of the roadside ecosystems formation and the possibility of further development of biodiversity conservation measures. In Ukraine and around the world, road infrastructure is an important economic and social object that has a negative impact on the environment. This takes place due to environmental pollution, fragmentation of habitats, biodiversity loss, etc. At the same time, on the roadsides the stations (microhabitats) are being formed. They can be a barrier to motor vehicle pollution and provide available shelters for living organisms. Road operation usually affects the structure of roadside vegetation. There is an increase in the number of of annual plant species and a decrease in perennials. Favourable conditions are also created for the spread of heliophytes and xerophytes. Roads are a source of chemical pollution that affects all components of roadside ecosystems. The amount of pollutants is mainly dependent on the traffic intensity and road width. The creation of roadside forest plantations significantly reduces the negative impact of vehicles. Wood plantations contribute to better carbon deposition, which is an integral part of many vehicle pollutants, and create a barrier for pollutants coming far from roads. Forest belt can also be a refuge for many species of animals and combine fragmented habitats around. Because plants and small animals at roadside stations are bound to their localities, they are able to accumulate much amount of ecotoxicants, especially heavy metals, which should be taken into account when conducting local business. For the living of animals in roadside stations, the characteristics of specific confined plant community, microclimate and landform are quite important. Due to the linearity and long distances, roadsides provide migration ways for many species. The developed roadside habitats may be the refugia for not only common, but for rare animals. We should conclude that further research of the environmental benefits of roadside ecosystems in the Steppe zone of Ukraine would allow developing effective measures for roadside management in the frames of nature conservation.

Keywords: roadside; forest belt; biodiversity; soil; pollutants

\section{Мережі автошляхів як особливі стації для живих організмів в умовах степової зони}

\author{
С. В. Єрмоленко, А. О. Гуслистий, А. М. Гагут, В. Я. Гассо, І. А. Іванько
}

Дніпровський національний університет імені Олеся Гончара, Дніпро, Україна

Аналіз літературних джерел дозволив визначити особливості формування придорожніх екосистем для можливості подальшої розробки заходів щодо збереження біорізноманіття. В Україні та всьому світі автотранспортна інфраструктура важливий економічний та соціальний об'єкт, який негативно впливає на навколишнє середовище. Це обумовлено забрудненням довкілля, фрагментацією екосистем, зменшенням біологічного різноманіття тощо. У той же час на узбіччях доріг формуються стації, які можуть слугувати бар'єром для автотранспортного забруднення та надавати прихисток різним видам живих організмів. Експлуатація доріг впливає на структуру придорожньої рослинності: збільшується кількість видів однорічних рослин та зменшується кількість видів багаторічних. Також створюються сприятливі умови для поширення геліофітів та ксерофітів. Автошляхи є джерелом хімічного забруднення, яке впливає на всі компоненти придорожніх 
екосистем. На кількість утворених полютантів переважно впливає інтенсивність руху та ширина доріг. Створення придорожніх лісових насаджень значно знижує негативний вплив автотранспорту. Деревні насадження сприяють кращому депонуванню вуглецю, який є складовою частиною багатьох складових викидів автотранспорту, та створюють бар'єр для полютантів, що надходять з автодоріг. Також лісосмуги можуть бути прихистком для багатьох видів тварин та поєднувати фрагментовані екосистеми. Однак, оскільки рослини придорожніх стацій є нерухомими об'єктами, вони здатні накопичувати великі концентрації екотоксикантів, в особливості важких металів, що слід ураховувати при веденні господарської діяльності. Для проживання тварин в умовах придорожніх стацій важливе значення має характеристика фітоценозу, мікроклімат та форма рельєфу. Через лінійність та великі відстані узбіччя автодоріг забезпечують можливості для міграції багатьом видам. В умовах придорожніх стацій можливе виникнення рефугіумів для рідкісних видів тварин. Таким чином, проведення досліджень екологічних функцій придорожніх стацій в умовах степової зони України дозволить розробити більш ефективні заходи управління узбіччями в природоохоронних цілях.

Ключові слова: узбіччя; лісосмуги; біорізноманіття; грунт; полютанти

\section{Вступ}

В останні роки у світі спостерігається стрімкий ріст кількості автотранспорту, який потребує збільшення кількості доріг (Abolmasova et al., 2019). На сьогодні автомобільна мережа та іiі інтенсивна експлуатація - один 3 вагомих джерел забруднення навколишнього середовища, особливо парниковими газами, викиди яких регулюються угодами для протидії глобальному потеплінню (Кіотська та Паризька угоди) (Poškas et al., 2018). Рівень викидів цих забруднювачів у вихлопних газах транспортних засобів $€$ токсичним та шкідливим для навколишнього середовища, а також для рослин та здоров'я людей (Grantz et al., 2003; Khalid et al., 2019; Khalid et al., 2020; Peter et al., 2016).

Експлуатація автотранспортних мереж відіграє значну роль у розповсюдженні інвазивних видів, фрагментації та руйнації екосистем (Meland et al., 2019). Через це організми, які знаходяться в придорожніх оселищах, зазнають різноманітних ризиків, наприклад смертність тварин на дорогах внаслідок міграцій та зміни умов існування (Kušta et al., 2014; Neumann et al., 2012; Wang et al., 2017). Навіть за наявності значного біорізноманіття та оптимальних умов існування у цих біотопах існує ризик виникнення екологічних пасток (Gardiner, 2018). Незважаючи на це, у прилеглих до автошляхів стаціях відбуваються закономірні сукцесії, які можуть надавати певні екосистемні послуги (Phillips et al, 2020). Залежно від особливостей видів та груп організмів узбіччя відіграють різну роль у підтриманні їх оптимальних умов існування. Якщо правильно розуміти процеси управління придорожніми екосистемами, то їх можливо використовувати для збереження різноманіття, особливо рідких видів рослин та тварин (Monasterolo et al., 2020; Phillips et al., 2020).

В Україні автомобільні дороги - важливий об'єкт інфраструктури, який забезпечує значні обсяги пасажирських перевезень, транспортування товарної продукції, корисних копалин тощо (Aulin et al., 2016). Значна частина доріг степової зони України проходить між сільськогосподарськими угіддями, які займають більше $60 \%$ відсотків площі країни, 3 яких розорані території складають майже 70 \% (Mironov \& Tkachuk, 2016; Muzyka et al., 2019). В умовах активного використання агроценозів узбіччя доріг можуть зберігати певне різноманіття та створювати рефугіуми для різних невеликих видів живих організмів (Arenas et al., 2017).

Метою нашої роботи $\epsilon$ аналіз сучасних наукових джерел для встановлення особливостей впливу автодорожніх магістралей на навколишнє середовище та оцінювання стану вивчення цього питання в степовій зоні України та в світі в цілому.

Особливості формування фітоценозу на узбіччях. У стаціях, утворених діяльністю доріг, виникає особливий мікроклімат, зумовлений значним освітленням, прогрівом дорожнього покриття (асфальту) тощо (Joly et al., 2011). При таких несприятливих умовах значно зменшується чисельність багаторічних рослин та збільшується домінування однорічних (Brown, 2011). Відомі випадки, коли придорожні стації слугували прихистком для зникаючих видів однорічних рослин, наприклад деяких представників роду Himantoglossum в умовах автошляхів країн Балканського та Апеннінського півостровів (Fekete et al., 2017). Біля доріг формуються умови для поширення геліофітів та ксерофітів (амброзія полинолиста Ambrosia artemisiifolia L., злинка канадська Erígeron canadensis (L.), чорнощир звичайний Iva xanthiifolia Nutt. тощо) (Kucher, 2015). При правильному управлінні подібними фітоценозами можливе створення осередків рідких видів рослин та відповідної кормової бази для тварин, що буде мати природоохоронну цінність (Auestad et al., 2011; Hovd \& Skogen, 2005).

Для поліпшення екологічних умов землеробства, запобігання втратам чорнозему та збереження вологи між автошляхами та полями створювалися лісозахисні смуги. В умовах степової зони України насадження зазвичай мають неоднорідну структуру та представлені такими видами: Acer platanoides L., Fraxinus excelsior L., Ulmus pumila L., Robínia pseudoacácia L., Acer negundo L., Gleditsia triacanthos L. та ін. (Ponomareva, 2015, 2016). Як свідчать результати багатьох наукових досліджень (Lukisha, 2013; Chornyavska, 2017), ці насадження виконують меліоративні функції - підвищують вологість повітря, регулюють швидкість вітру та сприяють розподілу снігу. Придорожні узлісся створюють особливі гідрологічні умови за рахунок перехвату стоку води 3 поверхні автодороги, що призводить до значного утримання вологи та вмісту мінеральних речовин у грунті. Це сприяє збільшенню вегетаційної маси та підвищенню репродуктивності рослин (Lamont et al., 1994, 2006). Також лісосмуги виступають бар'єром для полютантів, які переміщуються від автомобільних доріг 3 повітрям та поверхневим стоком (Heath et al., 1999; Janku, 2016).

Лісосмуги вздовж автошляхів здатні поєднувати фрагментовані екосистеми на регіональному рівні, оскільки деревинні насадження такого типу можуть використовуватися живими організмами як екологічні коридори (Prihod'ko \&. Chirkova, 2009). Для багатьох тварин ці штучні лісові насадження створюють більш сприятливий мікроклімат, що надає їм місце для прихистку (Yermolenko et al., 2019).

Особливості формування трунтів на узбіччях. Дослідження характеру змін умісту грунтового органічного вуглецю в чорноземі звичайному, обумовлених культивуванням деревних насаджень, є дуже важливим для розуміння особливостей поглинання i виділення парникових газів в умовах степової зони (Gorban et al., 2020). Автотранспорт - значне джерело забруднення вуглецевими газами, збільшення яких в атмосфері призвело до зміни кліматичних умов у світі (Léonardi \& Baumgartner, 2004). Інтенсивність секвестрації грунтового органічного вуглецю i його депонування в грунтах залежить від складної взаємодії між кліматом, грунтами, фітоценозом, а також хімічним складом підстилки, обумовленими домінуючими видами рослин (Lal, 2005). 
Деревні насадження, на відміну від трав'янистих рослин, краще впливають на біологічні, хімічні та фізичні властивості грунтів безпосередньо через їх глибокі корені, якість і кількість підстилки, що вони створюють (Day et al., 2010; Edmondson et al., 2014). Варто зазначити, що на кількісні показники загального вуглецю у придорожніх грунтах і рослинах впливають розмір дороги, інтенсивність дорожнього руху та сезонність (Khalid et al., 2020).

Особливості формування зооценозу на узбіччях. Узбіччя доріг можуть слугувати рефугіумами для зникаючих видів безхребетних, де вони можуть мати більшу чисельність порівняно 3 навколишніми екосистемами (Noordijk et al., 2008). Особливість узбіч відкриті грунти, які добре прогріваються, що може робити ïx рефугіумами для стенотопних термофільних видів безхребетних (Kirby, 1992). Подібні умови сприятливі, наприклад, для деяких видів турунів (Eversham \& Telfer, 1994). Згідно $з$ даними Timofeev (2016), за комплексом абіотичних та біотичних факторів тут складаються оптимальні умови для різнокрилих бабок, які дозволяють ім проникати в лісові екосистеми. Дослідженнями Heneberg et al. (2016) виявлено, що на узбіччі траси між містами Прага та Хомутов (Чеська Республіка), яка прокладена переважно між агроценозами, виникали спонтанні формування степових екосистем, на яких було виявлено 139 видів рослин та 164 види бджіл та ос.

Автомобільні шляхи можуть слугувати коридором для проникнення ксерофільних степових видів у лісові біогеоценози. За даними Євсюкова А. П. (Evsyukov, 2010), в умовах біогеоценозів дельти Волги вздовж узбіч може спостерігатися збільшення обсягів тваринних та рослинних залишків, що привертає увагу сапрофагів, наприклад Armadillidium vulgare (Latreille, 1804), Dermestes laniarius Illiger, 1801.

В умовах лісостепової зони України сформувалися ізольовані популяції інвазійного кліща-хижака Typhlodromus beglarovi (Kuznetsov, 1984), що, на думку Kolodochka \& Omeri (2010), є локальним ефектом впливу доріг, які можуть значно підвищити температуру повітря та пригнітити рухову активність харчових об'єктів кліща. Подібне явище також можливе і в степовій зоні.

Узбіччя автомобільних шляхів може створювати сприятливі умови для міграції територією степової зони деяких видів прямокрилих, серед яких $є$ i шкідники, наприклад італійська сарана Calliptamus italicus (Linnaeus, 1758). На думку Гавриленко В. С. (Havrylenko, 2015), це обумовлено тим, що порівняно $з$ природним субстратом автошляхи швидше прогріваються у ранковий час, що прискорює фізіологічні процеси комах. Також, на відміну від степу, на узбіччях росте більша кількість рослинмезофітів, яким C. italicus надає трофічну перевагу.

Дороги та узбіччя, на яких утворюються скупчення комах, приваблюють і тварин-ентомофагів, у тому числі плазунів. За спостереженнями Meek (2014), які проводились на ящірках Lacerta bilineata (Daudin, 1802) та Podarcis muralis (Laurenti, 1768), щільність ящірок на автошляхах західної Франції корелювалась залежно від кількості здобичі. Також зазначалося, що на чисельність ящірок впливали особливості рослинності узбіч, що дозволило рептиліям знаходити місця проживання i схованки.

Фітоценоз та характер ландшафту відіграє важливу роль у підтриманні видового різноманіття та чисельності малакофауни узбіч. При дослідженні кількості наземних молюсків на узбіччях автодоріг Мелітопольського району (Україна) М. В. Генсицький (Gensytskyy, 2019) припустив, що в умовах узбіч западини та пагорби 3 достатньою щільністю рослинності, на відміну від рівних ділянок 3 низькою щільністю, здатні краще утримувати вологу, тому утворюють більш сприятливі умови існування молюсків.
За наявності певних умов придорожні канави також здатні підтримувати різноманіття тварин. Так, за спостереженнями Johnson et al. (2016) i Homyack et al. (2016), було виявлено, що в умовах соснового лісу на території Північної Кароліни (США) деякі амфібії та рептилії зустрічаються у придорожніх канавах, оскільки в цих місцях створюються оптимальні умови для їх існування. Слід ураховувати, що будова придорожніх канав здатна впливати i на переміщення тварин. Наприклад, Zhang et al. (2010) при дослідженні міграцій молоді та дорослих особин малайської ропухи Duttaphrynus melanostictus (Schneider, 1799) встановили, що при проєктуванні канав слід ураховувати їх кут схилу, матеріал та глибину, що має важливе значення для пересування земноводних.

Мікромамалії також можуть знаходити прихисток у травостої узбіч, однак на нього впливає інтенсивність господарської діяльності: випас худоби та скошування трави. Наявність здобичі може, у свою чергу, приваблювати хижих ссавців. Так, наприклад, Сіренко В. зі співавторами (Sirenko et al., 2015) зазначають, що збільшення чисельності ящірок та мишоподібних гризунів в умовах узбіч деяких районів південного сходу України призвело до освоєння цих стацій перегузнею Vormela peregusna (Güldenstädt, 1770).

Антропогенний вплив доріг на навколишнс середовище. На розподіл забруднювачів впливають кліматичні умови та особливості придорожніх ландшафтів. Під час атмосферних опадів на автошляхах виникає поверхневий стік, який впливає на якість поверхневих та грунтових вод (Crabtree et al., 2006; Francey et al., 2010; Istenič et al., 2012; Pan and Miao, 2015; McIntyre et al., 2015; Barkdoll et al., 2016; Sattar et al., 2017). Дідура P. B. (Didura, 2016) у своїй роботі зазначив, що на ділянках узбіч, які знаходилися на височині, концентрація свинцю в грунті може 3 часом знижуватися, оскільки цей важкий метал зноситься поверхневим стоком у низовини, де його концентрація поступово зростає. Згідно 3 даними Tsihrintzis \& Hamid (1997), основними забруднювачами водойм США зваженими твердими частинками (50 \%) та поліциклічними ароматичними вуглеводнями (70 \%) $є$ стічні води з автомобільних шляхів.

В умовах міста узбіччя піддаються впливу інтенсивного забруднення. На кількісні і якісні показники складу токсикантів впливає кількість населення, наявність великих промислових об'єктів, час експлуатації доріг, інтенсивність транспортного потоку та організація вулично-дорожнього руху (кількість перехресть, затори тощо) (Pylypenko \& Skok 2018). Yan et al. (2018) проаналізували літературні дані стосовно вмісту важких металів у придорожніх грунтах таких міст, як Пекін (Китай), Мельбурн (Австралія), Торонто (Канада) та Сієна (Італія). Було виявлено, що більш високі концентрації $\mathrm{Cu}$ та $\mathrm{Pb}$ відмічено у м. Сієна, але це може бути наслідком більш тривалого віку місцевих доріг (мінімум 35 років) та інтенсивності руху (близько 50 тис. транспортних засобів/день) (Nannoni \& Protano, 2016).

Накопичення забруднювачів, які викидає автотранспорт, у рослинах може відбуватися двома шляхами: поглинанням 3 грунту та осіданням токсикантів на поверхню рослин 3 повітря (De Silva et al., 2020). Також слід ураховувати фізикохімічну характеристику грунтів, яка впливає на сорбцію токсикантів 3 них тканинами рослин. Відомо, що механічний склад, значення $\mathrm{pH}$ та іонообмінна здатність грунтів впливають на доступність мікроелементів (Kloke et al., 1984). Інтенсивність біоакумуляції полютантів у рослинах, що зростають у біотопах, прилеглих до автошляхів, може залежати від відстані до доріг та інтенсивності руху автотранспорту (Rodríguez-Flores, Rodríguez-Castellon, 1982; Zereini et al., 2001; Wang et al., 2018). 
Створення насаджень із плодово-ягідних видів рослин на узбіччях $\epsilon$ небажаним, оскільки їх плоди можуть містити значні концентрації токсикантів, які при потраплянні в організм тварин та людей здатні викликати отруєння. Pehluvan et al. (2015) виявили високі концентрації $\mathrm{Cu}, \mathrm{Cd}$ та $\mathrm{Pb}$ у плодах Prunus avium L., Morus nigra L., Prunus armeniaca L., Prunus persica L. Batsch, Prunus domestica L., Pyrus communis L., Crataegus oxyacantha L. та Rosa canina. L. , які росли на узбіччі однієї з трас Туреччини з інтенсивністю руху 4000 автомобілів на добу.

Автотранспортні засоби використовують різні види паливу, які при використанні мають певні наслідки для забруднення. Давидова I. В. та ін. (Davydova et al., 2003) у лабораторних умовах виявили, що грунти, які були забруднені альтернативним пальним, мали менший токсичний вплив на орибатид, ніж грунти, які були забруднені дизельним.

Для запобігання обледенінню доріг часто застосовують сіль $\mathrm{NaCl}$, яка при потраплянні у придорожні водні об'єкти може негативно впливати на пов'язаних 3 ними тварин. Так, наприклад, при концентраціях 0,39-1030,00 мг $\mathrm{NaCl}$ на 1 л води у пуголовок Lithobates sylvaticus (LeConte, 1825) виникали відхилення розвитку, зниження вгодованості та активності тощо (Sanzo \& Hecnar, 2006).

На відміну від рослин тварини є рухливими об'єктами, через що виникають труднощі визначення токсичного впливу саме автотранспорту. Також слід ураховувати тривалість життя та трофічні особливості видів. Так, наприклад, згідно 3 Scanlon (1991) у придорожніх екосистемах комахоїдні тварини можуть накопичувати більші кількості мікроелементів, ніж травоїдні.

\section{Висновки}

Аналіз наукових літературних джерел щодо антропогенного впливу автомагістралей на придорожні екосистеми показав, що дослідження цієї проблеми $\epsilon$ актуальним у світовому масштабі. Експлуатація існуючих автодоріг та будівництво нових автошляхів наносять значну шкоду придорожнім екосистемам: флорі, фауні та грунтам. Однак, ураховуючи специфічні властивості, вони можуть надавати прихисток певним видам і таким чином сприяти збереженню біорізноманіття та частково компенсувати негативний ефект автодоріг.

Більш детальне вивчення стану грунтів узбіч дасть змогу визначити інтенсивність іх секвестрації та депонування органічного вуглецю. Це важливо 3 огляду на те, що сорбція полютантів рослинами відбувається саме 3 грунту та залежить від механічного складу грунту, його $\mathrm{pH}$ та іонообмінної здатності.

При формуванні навколо доріг лісосмуг створюються захисні бар'єри від забруднювачів, шуму та руйнівних погодних явищ. Також рослинність на узбіччях стає прихистком для деяких видів фауни. Для здійснення екологічного управління узбіччями важливо враховувати особливості навколишніх екосистем, інтенсивність руху транспорту, ширину дорожнього полотна, ландшафтні та мікрокліматичні характеристики узбіч. Також треба брати до уваги, що придорожні стації можуть бути коридорами для проникнення інвазійних видів і міграцій шкідників.

\section{References}

Abolmasova, G., Pisnia, L., Cherepnov, I., \& Kalinin, I. (2019). Kompleksna ekologichna ocinka vplivu sistemi «avtomobil'doroga-seredovishche» na ob'ekti navkolishn'ogo prirodnogo seredovishcha [Comprehensive ecological assessment of the impact of the «car-road-environment» system on environmental objects]. Engineering of Nature Management, 4(14), 75-85 (in Ukrainian).
Arenas, J. M., Escudero, A., Mola, I., \& Casado, M. A. (2017). Roadsides: an opportunity for biodiversity conservation. Applied Vegetation Science, 20(4), 527-537.

Auestad, I., Rydgren, K., \& Austad, I. (2011). Road Verges: potential refuges for declining grassland species despite remnant vegetation dynamics. Annales Botanici Fennici, 48(4), 289-303.

Aulin V. V., Golub D. V., \& Grin'kiv A. V. (2016). Stupin' zabezpechennya nadijnosti ta yakosti pasazhirs'kih i vantazhnih avtomobil'nih perevezen' v Ukraïni nacional'nimi ta mizhnarodnimi standartami [The degree of reliability and quality of passenger and freight road transport in Ukraine by national and international standards]. Bulletin Of Engineering Academy Of Ukraine, 3, 156-162 (in Ukrainian).

Brown, R. N., \& Gorres, J. H. (2011). The use of soil amendments to improve survival of roadside grasses. HortScience, 46(10), 1404-1410.

Chornyavska I. R. (2017). Vplyv smuhovykh zakhysnykh lisovykh nasadzhen Pivdennoi zaliznytsi na rozpodil snihovoho pokryv [Influence of shelterbelts on snow cover surface distribution at southern railways of Ukraine]. Forestry and Forest Melioration, 130, 119-124 (in Ukrainian).

Davydova, I. V., Arystarkhova, E. A., Shchyrsky; V. V., \& Shulga, I. V. (2003). Vikoristannya gruntovih klishchiv Oribatei dlya bioindikaciï ta biotestuvannya zagal'noï toksichnosti gruntu [The use of soil-inhabiting mites oribatei for bioindication and biotesting of the general soil toxicity]. Scientific Bulletin of UNFU, 13(5), 113-117 (in Ukrainian).

Day S. D., Wiseman P. E., Dickinson S. B., \& Harris J. R. (2010). Tree root ecology in the urban environment and implications for a sustainable rhizosphere. Arboriculture and Urban Forestry, 36, 193-205.

De Silva, S., Ball, A. S., Indrapala, D. V., \& Reichman, S. M. (2020). Review of the interactions between vehicular emitted potentially toxic elements, roadside soils, and associated biota. Chemosphere, 128135.

Dean, W., \& Milton, S. (2003). The importance of roads and road verges for raptors and crows in the Succulent and NamaKaroo, South Africa. Ostrich, 74(3-4), 181-186.

Didura, R. V., (2016). Vmist vazhkih metaliv u dorozhn'omu landshafti avtomagistrali Kiiv-Odessa [Content of heavy metals in the road landscape of the Kiev-Odessa highway]. Scientific notes of Vinnytsya State Pedagogical University named after Michailo Kotzubynsky. Series: Geography, 28(3-4), 57-64 (in Ukrainian).

Edmondson, J. L., O'Sullivan, O. S., Inger, R., Potter, J., McHugh, N. Gaston, K. J., \& Leake, J. R. (2014). Urban tree effects on soil organic carbon. PLoS ONE, 9(7), e101872.

Eversham, B. C., \& Telfer, M. G. (1994). Conservation value of roadside verges for stenotopic heathland Carabidae: corridors or refugia? Biodiversity and Conservation, 3(6), 538-545.

Evsyukov, A. P. (2010). Mezofauna deltyi Dona i ee izmeneniya pod vliyaniem antropogennyih faktorov [Mesofauna of the Don delta and its changes under the influence of anthropogenic factors]. Avtoref. diss. kand. biol. nauk. Rostov-na-Donu, 24 (in Russian).

Fekete, R., Nagy, T., Bódis, J., Biró, É., Löki, V., Süveges, K., Takácsac, A., Tökölyi, J., \& Molnár, A. (2017). Roadside verges as habitats for endangered lizard-orchids (Himantoglossum spp.): Ecological traps or refuges?. Science of the Total Environment, 607, 1001-1008.

Gardiner, M. M., Riley, C. B., Bommarco, R., \& Öckinger, E. (2018). Rights of way: a potential conservation resource. Frontiers in Ecology and the Environment, 16(3), 149-158.

Gensytskyy, M. V. (2019) Vpliv avtotransportu ta obslugovuvannya dorig na vidovij sklad i chisel'nist' nazemnih molyuskiv [Influence of motor transport and road maintenance on the species composition and number of terrestrial mollusks]. Ekologiya - filosofiya isnuvannya lyudstva: zb. nauk. prac'. pp. 31-34 (in Ukrainian). 
Gorban, V., Huslystyi, A., Kotovych, O., \& Yakovenko, V. (2020). Changes in Physical and Chemical Properties of Calcic Chernozem Affected by Robinia pseudoacacia and Quercus robur Plantings. Ekológia (Bratislava), 39(1), 27-44.

Grantz, D., Garner, J. H., \& Johnson, D. (2003). Ecological effects of particulate matter. Environment International, 29(2-3), 213-239.

Havrylenko, V. S. (2015). Rol' dorig i stezhok v zhittediyal'nosti tvarin biosfernogo zapovidnika Askaniya-Nova [The role of roads and trails in the life of animals of the Askania-Nova Biosphere Reserve]. News Biosphere reserve "Askania Nova", (17), 44-53 (in Ukrainian).

Heath, B. A., Maughan, J. A., Morrison, A. A., Eastwood, I. W., Drew, I. B., \& Lofkin, M. (1999). The influence of wooded shelterbelts on the deposition of copper, lead and zinc at Shakerley Mere, Cheshire, England. Science of The Total Environment, 235(1-3), 415-417.

Heneberg, P., Bogusch, P., \& Řezáč, M. (2016). Roadside verges can support spontaneous establishment of steppe-like habitats hosting diverse assemblages of bees and wasps (Hymenoptera: Aculeata) in an intensively cultivated central European landscape. Biodiversity and Conservation, 26(4), 843-864.

Homyack, J. A., O’Bryan, C. J., Thornton, J. E., \& Baldwin, R. F. (2016). Community occupancy of herpetofauna in roadside ditches in a managed pine landscape. Forest Ecology and Management, 361, 346-357.

Hovd, H., \& Skogen, A. (2005). Plant species in arable field margins and road verges of central Norway. Agriculture, Ecosystems Environment, 110(3-4), 257-265.

Janku, K., Mana, M., \& Arczyńska-Chudy E. (2016). Quantitative analysis of shelterbelts adjacent to fields exposed to road pollution in the area of the city of Poznan. Forestry Letters, 109(10), 47-54.

Johnson, B. A., Homyack, J. A., Barrett, K., \& Baldwin, R. F. (2016). Factors influencing herpetofaunal assemblages of aquatic systems in a managed pine forest. Forest Ecology and Management, 379, 124-132.

Joly, M., Bertrand, P., Gbangou, R. Y., White, M.-C., Dubé, J., \& Lavoie, C. (2011). Paving the Way for Invasive Species: Road Type and the Spread of Common Ragweed (Ambrosia artemisiifolia). Environmental Management, 48(3), 514-522.

Khalid, N., Masood, A., Noman, A., Aqeel, M., \& Qasim, M. (2019). Study of the responses of two biomonitor plant species (Datura alba \& Ricinus communis) to roadside air pollution. Chemosphere, 235, 832-841.

Khalid, N., Noman, A., Masood, A., Tufail, A., Hadayat, N., Alnusairi, G. S. H., \& Aqeel, M. (2020). Air pollution on highways and motorways perturbs carbon and nitrogen levels in roadside ecosystems. Chemistry and Ecology, 36(9), 868-880.

Kirby, P. (1992). Habitat management for invertebrates: a practical handbook. RSPB.

Kloke, A., Sauerbeck, D. R., \& Vetter, H. (1984). The Contamination of Plants and Soils with Heavy Metals and the Transport of Metals in Terrestrial Food Chains. Changing Metal Cycles and Human Health, 113-141.

Kolodochka, L., \& Omeri, I. (2010). New data on successful invasion of mediterranean predatory mite Typhlodromus Beglarovi (Parasitiformes, Phytoseiidae) into the forest-steppe of Ukraine. Vestnik zoologii, 44(2), e-23-e-23.

Kucher, O. O. (2015). Invasive species in the flora of the Starobilsk grass-meadow steppe (Ukraine). Environmental Socio-economic Studies, 3(2), 11-22.

Kušta, T., Holá, M., Keken, Z., Ježek, M., Zíka, T., \& Hart, V. (2014). Deer on the railway line: spatiotemporal trends in mortality patterns of roe deer. Turkish Journal of Zoology, 38 , $479-485$.

Lal, R. (2005). Forest soils and carbon sequestration. Forest Ecology and Management, 220(1-3), 242-258.

Lamont, B. B., Connell, S. W., \& Bergl, S. M. (1991). Seed Bank and Population Dynamics of Banksia cuneata: The Role of Time, Fire, and Moisture. Botanical Gazette, 152(1), 114-122.
Lamont, B. B., Rees, R. G., Witkowski, E. T. F., \& Whitten, V. A. (1994). Comparative Size, Fecundity and Ecophysiology of Roadside Plants of Banksia hookeriana. The Journal of Applied Ecology, 31(1), 137.

Lamont, B. B., Written, V. A., Witkowski, E. T. F., Rees, R. G., \& Enright, N. J. (2006). Regional and local (road verge) effects on size and fecundity in Banksia menziesii. Australian Journal of Ecology, 19(2), 197-205.

Léonardi, J., \& Baumgartner, M. (2004). CO2 efficiency in road freight transportation: Status quo, measures and potential. Transportation Research Part D: Transport and Environment, 9(6), 451-464.

Lukisha V. V. (2012). Ekolohichni funktsii polezakhysnykh lisovykh nasadzhen [Ecological functions of field windbreak plantation]. Ecological Sciences, 1(1), 56-54.

Meek, R. (2014). Temporal distributions, habitat associations and behaviour of the green lizard (Lacerta bilineata) and wall lizard (Podarcis muralis) on roads in a fragmented landscape in Western France. Acta Herpetologica, 9(2), 179-186.

Meland, S., Gomes, T., Petersen, K., Håll, J., Lund, E., Kringstad, A., \& Grung, M. (2019). Road related pollutants induced DNA damage in Dragonfly nymphs (Odonata, Anisoptera) living in highway sedimentation ponds. Scientific reports, 9(1), 1-15.

Mironov V. V., \& Tkachuk A. I. (2016). Ekonomichnyi, pravovyi ta ekolohichnyi zakhyst zemel v Ukraini: istoriia stanovlennia ta suchasnyi stan [Economic, legal and ecological protection of land in Ukraine:history of formation and present state]. Taurian Scientific Bulletin. Economic sciences, 96, 32-41.

Monasterolo, M., Poggio, S. L., Medan, D., \& Devoto, M. (2020). Wider road verges sustain higher plant species richness and pollinator abundance in intensively managed agroecosystems. Agriculture, Ecosystems Environment, 302, 107084.

Muzyka, P., Urba, S., \& Goncharenko, L. (2019). Analysis and efficiency of using land resources in Ukraine. Scientific Notes of Taurida National V.I. Vernadsky University. Series: Economy and Management, 4(69).

Neumann, W., Ericsson, G., Dettki, H., Bunnefeld, N., Keuler, N. S. Helmers, D. P., \& Radeloff, V. C. (2012). Difference in spatiotemporal patterns of wildlife road-crossings and wildlifevehicle collisions. Biological Conservation, 145(1), 70-78.

Noordijk, J., Sýkora, K. V., \& Schaffers, A. P. (2008). The conservation value of sandy highway verges for arthropodsimplications for management. Proceedings of the Netherlands Entomological Society Meeting, 19, 75-93.

Pehluvan, M., Turan, M., Kaya, T., \& Şimsek, U. (2015). Heavy metal and mineral levels of some fruit species grown at the roadside in the east part of Turkey. Fresenius environmental bulletin, 24, 1302-1309.

Peter, O. O., Olushola, A. A., Rasaki, A. S., Olusanmi, E. O., \& Tolulope, B. A. (2016). Assessment of some heavy metals in the surrounding soils of an automobile battery factory in Ibadan, Nigeria. African Journal of Environmental Science and Technology, 10(1), 1-8.

Phillips, B. B., Bullock, J. M., Osborne, J. L., \& Gaston, K. J. (2020). Ecosystem service provision by road verges. Journal of Applied Ecology, 57(3), 488-501.

Phillips, B. B., Wallace, C., Roberts, B. R., Whitehouse, A. T., Gaston, K. J., Bullock, J. M., Dicks, L.V. \& Osborne, J. L. (2020). Enhancing road verges to aid pollinator conservation: A review. Biological Conservation, 108687.

Ponomareva, O. A. (2016). Stan primagistral'nih lisosmug bilya smt Kirilivka Zaporiz'koï oblasti [Condition of main forest belts near Kyrylivka township, Zaporizhia region]. Problems of bioindications and ecology, 21(1-2), 40-53 (in Ukrainian).

Ponomareva, E. A. (2015). Analiz sostoyaniya zashchitnyh pridorozhnyh nasazhdenij trassy Dnepropetrovsk-Zaporozh'e [Analysis of state of shelterbelts on the highway Dnepropetrovsk-Zaporozhye]. Vestnik Don State Agrarian University, 3 (17.1), 52-60 (in Russian).

Poškas, R., Sirvydas, A., Poškas, P., Jouhara, H., Striūgas, N., Pedišius, N., \& Valinčius, V. (2018). Investigation of warm 
gas clean-up of biofuel flue and producer gas using electrostatic precipitator. Energy, 143, 943-949.

Prihod'ko, S. A., \& Chirkova, O. V. (2009). Efektivnist' funkcionuvannya lisosmug yak ekologichnih koridoriv $\mathrm{v}$ ekomerezhi [Efficiency of forest belts functioning as ecological corridors in the ecological network]. Industrial Botany, 9, 25-31 (in Ukrainian).

Pylypenko, Yu. V., \& Skok, S. V. (2018). Otsinka rivnya zabrudnennya Iruntu vazhkimi metalami v mezhah mis'koï sistemi (na prikladi m. Herson) [Evaluation of the level of soil contamination by heavy metals within the limits of urban system (through the example of Kherson city)]. Biodiversity, ecology and experimental biology, 17, 138-145 (in Ukrainian).

Rodríguez-Flores, M., \& Rodríguez-Castellón, E. (1982). Lead and cadmium levels in soil and plants near highways and their correlation with traffic density. Environmental Pollution Series B, Chemical and Physical, 4(4), 281-290.

Sanzo, D., \& Hecnar, S. J. (2006). Effects of road de-icing salt $(\mathrm{NaCl})$ on larval wood frogs (Rana sylvatica). Environmental Pollution, 140(2), 247-256.

Scanlon, P. F. (1991). Chapter 8 Effects of Highway Pollutants Upon Terrestrial Ecosystems. Studies in Environmental Science, 281-338.

Sirenko, V., Sirenko, N., Podpriatov, O., \& Sirenko, O (2015). Stan populyaciï pereguzni (Vormela peregusna) na pivdennomu skhodi Ukraini [State of the Marbled Polecat (Vormela peregusna) Population in Southeastern Ukraine]. Proceedings of the Theriological School, (13), 37-41 (in Ukrainian).

Timofeev, A. N. (2016). The ecology and behavioral features of dragonflies (Insecta, Odonata) in the forest-steppe zone of Central Chernozem region. Russian Journal of Ecology, 47(5), 501-507.
Voloschynska, S. S. (2008). Bioindikaciya stanu zabrudnennya dovkillya vazhkimi metalami (na prikladi avtomagistrali «Kiïv-Varshava») [Bioindication of the heavy metals environmental pollution (on the example of highway «KyivWarsaw»)]. Visnyk of Dnipropetrovsk University. Biology. Ecology, 16(2), 24-28 (in Ukrainian).

Wang, H., Nie, L., Xu, Y., Li, M., \& Lv, Y., (2018). Trafficemitted metal status and uptake by Carex meyeriana Kunth and Thelypteris palustris var. Pubescens Fernald growing in roadside turfy swamp in the Changbai Mountain area, China. Environmental Science and Pollution Research, 25(19), $18498 \mathrm{e} 18509$.

Wang, T, Harvey, J., \& Kendall, A. (2014). Reducing greenhouse gas emissions through strategic management of highway pavement roughness. Environmental Research Letters, 9, 034007.

Wang, Y., Guan, L., Piao, Z., Wang, Z., \& Kong, Y. (2017). Monitoring wildlife crossing structures along highways in Changbai Mountain, China. Transportation Research Part D: Transport and Environment, 50, 119-128.

Yermolenko, S. V., Gasso, V. Y., Hagut, A. M., Bobyliov, Y. P., \& Hasso I. A. (2019). Rol' lisozahisnih nasadzhen' u pidtrimanni bioriznomanittya gerpetofauni stepovogo Pridniprov'ya [Role of forest shelterbelts in conservation of herpetofauna biodiversity in the steppe Dnieper area]. Problems of bioindications and ecology, 24(1), 93-101.

Zereini, F., Wiseman, C., Alt, F., Messerschmidt, J., Müller, J., \& Urban, H., (2001). Platinum and rhodium concentrations in airborne particulate matter in Germany from 1988 to 1998. Environmental Science \& Technology. 35, 1996e2000.

Zhang, Z., Yang, H., Yang, H., Li, Y., \& Wang, T. (2010). The impact of roadside ditches on juvenile and sub-adult Bufo melanostictus migration. Ecological Engineering, 36(10), $\underline{1242-1250 .}$. 